\title{
ПРОБЛЕМИ ОРГАНІЗАЦІЇ НАВЧАННЯ У РАМКАХ ПРОГРАМИ ОТРИМАННЯ ПОДВІЙНОГО ДИПЛОМА
}

\author{
В. М. Лісовий, В. А. Капустник, І. В. Завгородній, Н. В. Семенова \\ Харківський національний медичний університет
}

\section{PROBLEMS OF ORGANISATION OF STUDY WITHIN DOUBLE DIPLOMA PROGRAM}

\author{
V. N. Lisovy, V. A. Kapustnyk, I. V. Zavhorodniy, N. V. Semenova \\ Kharkiv National Medical University
}

\begin{abstract}
У статті розглянуто проблеми, з якими стикаються майбутні фахівці під час навчання за програмами 3 метою отримання подвійного диплома. Проаналізовано відомі моделі програм з отримання подвійного диплома.

The problems faced by future specialists in the getting of double diploma are described in the article. Model programs of getting of double diploma are analyzed.
\end{abstract}

Вступ. Програма "Подвійний диплом" вже тривалий час діє в Україні, підтримана Міністерством освіти і науки, передбачає отримання двох дипломів, один з яких - європейського зразка. Досі небагато університетів долучаються до іï реалізації, зокрема через проблеми в отриманні закордонних віз, низький рівень володіння іноземною мовою, відсутність мотивації та складність професійної, самореалізації фахівців наринку праці, тощо.

Основна частина. Розвиток спільних програм стає одним із магістральних напрямків розвитку міжнародного співробітництва між вузами-партнерами різних країн світу. Міжнародні експерти в галузі вищої освіти переконані в тому, що жодна інша форма взаємодії ВН3 не дає таких вагомих результатів у розвитку співпраці з зарубіжними партнерами, як спільні програми. Так, професор Філіп Альбах, відповідаючи на питання про роль і значення міжнародних асоціацій університетів, підкреслив, що програми подвійних дипломів більш значущі, ніж асоціації у вирішенні цілого ряду прагматичних завдань, які ведуть до інтернаціоналізації університетів і до підвищення професійної мобільності молодих фахівців [1].

Україна має невеликий досвід впровадження програм подвійних дипломів порівняно з СС, Росією та іншими країнами. Тому в нашій країні актуальним залишається питання розширення сфери співробітництва ВНЗ з іноземними партнерами, зокрема в галузі створення та впровадження програм подвійних дипломів.

() В. М. Лісовий, В. А. Капустник, І. В. Завгородній,

Н. В. Семенова
Практикуються три основні моделі цього виду академічної підготовки:

- Програма подвійних ступенів, коли кожний ВНЗпартнер присвоює свій власний ступінь студентові, який виконав усі визначені взаємними домовленостями вимоги.

- Спільний ступінь, навпаки, становить єдиний документ, що затверджується всіма ВНЗ-учасниками консорціуму. Іноді модель подвійних ступенів включають до категорії спільного ступеня, що викликає нерозуміння не тільки у студентства, а й серед академічної громадськості та освітніх установ і влади.

- Третя модель $є$, по суті, комбінацією двох перших 3 більшим чи меншим ухилом у бік однієї з них.

Кожна 3 цих моделей має свої сильні та слабкі сторони. На перший погляд, найбільшу гнучкість 3 точки зору мобільності студентів та обміну викладачами надає перша модель. Однак у цьому випадку мобільність втрачає сенс через ідентичність програм. А сенс і привабливість програм подвійних дипломів полягає саме в тому, щоб кожен партнер міг зробити внесок вклад своїми напрацюваннями або ресурсами, яких немає в університеті-партнері.

Спільні програми, засновані на синергіїунікального досвіду кожного боку, дозволяють розробити програми, спрямовані на формування у студентів у кожному з університетів-партнерів таких окремих груп компетенцій, які взаємно доповнюють одна одну. При цьому занадто вузька спеціалізація кожного партнера також непродуктивна, оскільки перешкоджає співпраці викладачів. 
Нині більшість програм відповідає другій моделітакі програми складають близько 60 \% всіх спільних програм. Тільки десять відсотків програм має ідентичну структуру в кожному університеті-партнері, i близько тридцяти відсотків будується відповідно до третьої моделі, яка найчастіше реалізується у спільних програмах за участю країн, які не є членами $\in C$, в яких навчаються студенти другого циклу на завершальному етапі (5-й або 6-й рік) [2].

У цьому зв'язку всі моделі подвійних дипломів (спільних ступенів) вимагають найвищого рівня довіри між партнерами, найсуворішого контролю за розробкою та впровадженням навчального плану, а також безперервного та динамічного оперативного співробітництва. Більше того, найчастіше студенти проводять більшу частину часу не в рідному ВН3, а в приймаючому, що тягне за собою зовсім інші вимоги до таких студентів.

Разом з тим, у ряді країн законодавство не допускає внесення будь-якого додаткового тексту в офіційно затверджений документ (диплом або сертифікат). Треба сказати, що розробка відносно прийнятних для багатьох європейських ВНЗ структурних моделей програм подвійних дипломів (спільних ступенів) була й досі залишається однією з найскладніших проблем, яка ще чекає свого рішення.

Отже, основними проблемами є відсутність систематичної і досить повної інформації про ці програми в центральних органах освіти, а іноді й на сайтах самих університетів, несумісність термінів навчального року, неузгодженість навчальних планів, недосконале знання мови українськими студентами.

За кордоном вартість навчання значно нижча, ніж у вітчизняних ВНЗ. Це пояснюється тим, що в інших країнах держава фінансує вищу освіту. В Україні держбюджет покриває лише половину витрат на кому-

\section{Література}

1. Мартыненко Е. В. Создание и сопровождение программ двойных дипломов : учеб. пособие / Е. В. Мартыненко.-М. : РУДН, 2008. - 123 с. нальні послуги та виплату заробітної плати. Решта видатків лягає на плечі студентів, які навчаються на платній формі навчання. Однак якщо підсумувати ціну навчання, проживання та харчування у закордонних ВНЗ, то витрати будуть значно вищі, ніж в Україні.

У деяких країнах немає диференціації на дипломи приватних та державних ВНЗ, хоча рівень якості освіти у них різний. Звичайно, кожен сам вирішує, де йому здобувати освіту, однак у результаті такого навчання кращі роки можуть бути змарновані.

Не можна сказати, що за кордоном, зокрема у Польщі, вища освіта якісніша. Це питання дуже індивідуальне. Якщо абітурієнт не має базової підготовки, то він не зможе продовжити навчання ані в Польщі, ані в Україні. Студент повинен вміти вчитися та мати чітку мотивацію. Більше того, у Свропі поняття стипендіального забезпечення відсутнс. Провідні університети світу розташовані в невеликих містечках, оскільки велике місто забирає у студента багато часу. Також треба врахувати психологічний вплив на студента. Невизнання у Європі українських дипломів це лише формальність. Хороший фахівець завжди знайде можливість працевлаштування. Головне - показати свої знання та вміти їх застосовувати. У Європі працюють мобільні школи перекваліфікації, які в максимально короткий термін дозволяють привести диплом у відповідність до європейських вимог. Наприклад, у лондонських школах англійську мову викладають й українські випускники. Хіба це не показник?

Висновки. Враховуючи проблемні питання, з якими стикаються українські студенти при навчанні за кордоном, доцільним $€$ подальший розвиток системи подвійного диплома. Він потребує поглибленого вивчення іноземної мови, мотиваційної поведінки студентів $з$ урахуванням майбутньої гідної фахової та соціальної реалізації на ринку праці України.

2. Болонский процесс и его значение для России. Интеграция высшего образования в Европе. -М. : РЕЦЭП, 2005. $-199 \mathrm{c}$.

Отримано 26.02.14 